\title{
Managerial Creativity and Work Motivation of Secondary School Tribal Teachers In Relation To Their Occupational Self Efficacy
}

\author{
${ }^{1}$ Mr. Firdoss Rashid \\ M. Phil Scholar Lovely Faculty of Education Lovely Professional University Phagwara
}

\begin{abstract}
The purpose of the study was to find out the difference in managerial creativity and work motivation of secondary school tribal teachers in relation to their occupational self efficacy. The study was descriptive in nature and conducted over a sample of 60 secondary school tribal teachers in Kulgam, Shopian and Anantnag districts of Jammu and Kashmir State. Both male and female tribal teachers were selected as a sample with equal distribution of 30 males and 30 females by using purposive sampling technique. For collection of data, the investigator has used Managerial Creativity scale, Work Motivation Questionnaire and Occupational Self Efficacy scale. For the purpose of analysis and interpretation data, the investigator has also used t-test and corelation. The results of the study were: (a). There exists no significant difference in managerial creativity of secondary school male and female tribal teachers, $(b)$. There exists no significant difference in work motivation of secondary school male and female tribal teachers, (c). There exists no significant difference in occupational self efficacy of secondary school male and female tribal teachers, $(d)$. There exists positive relationship between managerial creativity and occupational self efficacy of secondary school tribal teachers, (e). There exists no significant relationship between work motivation and occupational self efficacy of secondary school male tribal teachers, $(f)$. There exists positive relationship between work motivation and occupational self efficacy of secondary school female tribal teachers.
\end{abstract}

Keywords: Managerial Creativity, Work Motivation, Occupational Self- Efficacy.

\section{Introduction}

Creative teaching is a highly complex endeavour that requires a broad array of skills and dispositions. Contextual pressures on educators largely prescribe the most effective pedagogical work processes. The immediate classroom context demands exceptional plans and managerial skills, facilitative leadership, flexibility, pattern perception, and intuitive capacities. The large, societal context often pressures teachers to confine their practice to insular, one-sided perspectives on teaching and learning. Non-reflective compliance with dogmatic philosophies or ideologies and insular practices eroded the professional decision making that underpins instructional creativity. The most creative teachers preserve their professionalism by finding artful ways to keep their students creative, even in confining conditions. Creative teaching demands exceptional breadth of skills and entails the implicit invitation to develop many of these skills to very high levels of proficiency. Some of this breadth derived from the multifaceted nature of teachers work and the diverse professional roles they fulfil. A typical teacher is responsible for short and long-range planning, diagnosis of students, development levels and learning differences; motivation, discipline, counselling, strategic implementation of diverse, complex instructional strategies, public-relations initiatives, and artful problem solving. An effective teacher handles all of this while mastering, to the extent possible, the most salient knowledge within one or more academic disciplines. Creativity needs to be buttressed by support from the organisation and good managerial skills to obtain good results. It is also asserted that encouraging creativity and innovation provides opportunities for managers to influence the course of organisational productivity.

Creativity in Management is advanced as referring to the ability to solve problems in an exceptionally competent and original way. Managerial creativity is described as the process of employing playfully exploratory rather than a mechanical approach in problem solving by a person who is open, curious and imaginative to find solution or designs that are novel and useful for the process of planning, organising, implementing and controlling to determine and achieve the organisational objectives in a dynamic environment. In a nutshell, managerial creativity refers to the novel multidimensional and fluent ideas related to different functions of management. It involves creative behaviours of manager which produce interesting or useful novelty. Creativity has been defined in many ways, ranging from "spark of genius", "super energy", "divergent thinking" to the problem solving process for novel and valuable output by a large number of scholars.

Gundry et al, (1994) have taken four perspectives of creativity and grouped them into following categories:

- The attribute theory holds that specific characteristics and traits predispose an individual to be perceived as "creative".

- The conceptual skill theory focuses on cognition, an act of awakening new thoughts, reassembling old learning and examining assumptions to new theories, new paradigms and new awareness. 
- The behavioural theory centres on the actions and activities that bring something new into being.

- The process theory holds that creativity is a highly complex, multifaceted phenomenon that relies on individual talents, skills and actions as well as organisational conditions.

Together with these perspectives describe that an individual who has some creative attributes along with specific skills may become predisposed to perform creativity. Amabile (1997) is of the views that intrinsic motivation principle of creativity applies not only to scientific creativity, but to business creativity as well. She proposes that all humans with normal capacities are able to produce at least moderately creative work in some domain many a times and that the social environment (the work environment) can influence both, the level and frequency of creative behaviour. Her componential theory of individual creativity includes three major components, each of which is necessary for creativity in any given domain: expertise, creative thinking skill and intrinsic task motivation. It suggests that creativity is most likely to occur when people's skills overlap with their strongest intrinsic interests and their deepest passions. Motivation is one of the most basic elements of human behaviour. Motivational theories attempt to explain how effort is generated and channelled (Werner and De Simone, 2006). Therefore, researchers and practitioners alike have devoted a considerable amount of energy to understanding teachers" motivation. However, considering the multiple tasks that teachers have to perform, it may be difficult to identify with precision the motivational processes underlying each given task and their relative impact on teachers' psychological functioning. Self-efficacy is the people's beliefs about their capabilities to produce designated levels of performance that exercise influence over events that affect their lives. Self-efficacy beliefs determine how people feel, think, motivate themselves and behave. Such beliefs produce these diverse effects through four major processes. They include cognitive, motivational, affective and selection processes. A strong sense of efficacy enhances human accomplishment and personal well-being in many ways. People with high assurance in their capabilities approach difficult tasks as challenges to be mastered rather than as threats to be avoided. Such an efficacious outlook fosters intrinsic interest and deep engrossment in activities. They set themselves challenging goals and maintain strong commitment to them. They heighten and sustain their efforts in the face of failure. They quickly recover their sense of efficacy after failures or setbacks. They attribute failure to insufficient effort or deficient knowledge and skills which are acquirable. They approach threatening situations with assurance that they can exercise control over them. Such an efficacious outlook produces personal accomplishments, reduces stress and lowers vulnerability to depression.

In contrast, people who doubt their capabilities shy away from difficult tasks which they view as personal threats. They have low aspirations and weak commitment to the goals they choose to pursue. When faced with difficult tasks, they dwell on their personal deficiencies, on the obstacles they will encounter, and all kinds of adverse outcomes rather than concentrate on how to perform successfully. They slacken their efforts and give up quickly in the face of difficulties. They are slow to recover their sense of efficacy following failure or setbacks. Because they view insufficient performance as deficient aptitude it does not require much failure for them to lose faith in their capabilities. They fall easy victim to stress and depression. Bandura (1997) has described self efficacy as, "the belief in one's capability to organize and execute the courses of action required to produce given attainments." According to him, the concern of self efficacy is with the judgments of what an individual can do in some situations or domains with the skills that he/she possesses. Furthermore, self efficacy as a domain-specific construct has been understood as the belief of an individual about his/her competence in a particular domain or context. Although relatively unexplored, the construct of occupational self-efficacy has many implications for organizations. Empirical research reveals that occupational self efficacy is positively related with many organizationally relevant variables, such as organizational commitment, job satisfaction, and preparedness for organizational change (Schyns, 2004; Schyns \& von Collani, 2002). The most general self efficacy assessments consist of an omnibus- type instrument that attempts to measure a general sense of confidence. Bandura $(1986,1997)$ argued that such general measures create problems of predictive relevance and are obscure about just what is being assessed. Marlatt, Baer and Quigley (1995) studied the influence of efficacy beliefs on the resistance of drug use, changing of use of habits and relapse prevention; they found out that self efficacy affects controlled use or abstinence and coping with the relapses. Self efficacy is commonly understood as being domain specific that is one can have more or less firm of self beliefs in different or particular situations of functioning. But some researches have also conceptualized a generalized sense of self efficacy. It refers to a global confidence in one's coping ability across a wide range of demanding or novel situations. General self efficacy aims at a broad and stable sense of personal competence to deal effectively with a variety of stressful situations (Schwarzer, 1994). Bandura (1997) argued that efficacy beliefs are multifaceted and contextual, but the level of generality of the efficacy items within a given domain of functioning varies depending on the degree of situations, resemblance and foresee ability of task.

In the light of above discussion, the study will be significant for following reasons; (a) it will be of value to both current and prospective practioners. If a relationship will exist between the managerial creativity, work motivation and occupational self efficacy of teachers in actuality, then school teachers as responsible bodies of schools will get direction to modify their own administrative behaviour, to promote a more positive 
and productive work motivation and occupational self efficacy in their specific schools; (b) The results of this research will be used in teacher preparation programs and other school development related strategies and policies. Therefore, the study has immense importance to study the unbalanced managerial creativity leads to unproductive work motivation and occupational self efficacy results into lower performance and productivity of other school bodies and associates.

\section{Objectives Of The Study}

- To study the managerial creativity of secondary school male and female tribal teachers.

- To study the work motivation of secondary school male and female tribal teachers.

- To study the occupational self efficacy of secondary school male and female tribal teachers.

○ To find out the relationship between managerial creativity and occupational self-efficacy of secondary school tribal teachers.

- To find out the relationship between work motivation and occupational self-efficacy of secondary school male tribal teachers.

- To find out the relationship between work motivation and occupational self-efficacy of secondary school female tribal teachers.

\section{HYPOTHESES OF THE STUDY}

- There exists no significant difference in managerial creativity of secondary school male and female tribal teachers.

- There exists no significant difference in work motivation of secondary school male and female tribal teachers.

- There exists no significant difference in occupational self-efficacy of secondary school male and female tribal teachers.

- There exists no significant relationship between managerial creativity and occupational self- efficacy of secondary school tribal teachers.

- There exists no significant relationship between work motivation and occupational self- efficacy of secondary school male tribal teachers.

- There exists no significant relationship between work motivation and occupational self- efficacy of secondary school female tribal teachers.

\section{DELIMITATIONS OF THE STUDY}

The present study was delimited to:

- Kulgam, Anantnag and Shopian districts of Jammu and Kashmir only;

- It was further delimited to 180 teachers (90 male and 90 female teachers) only;

- It was further confined to three variables i.e. Managerial Creativity, Work Motivation and Occupational Self Efficacy only.

\section{Research Method}

For the present study descriptive survey method has been used by the investigator.

\section{SAMPLING}

The sampling frame of the present study comprises all the tribal secondary school teachers working in government secondary schools in Kulgam, Anantnag and Shopian districts of Kashmir valley. The investigator has also taken 60 tribal teachers ( 30 male and 30 female) as sample for his investigation by using Purposive random sampling technique. The investigator has randomly selected the sample districts and for the availability of tribal teachers, the investigator has purposively taken some schools.

\section{TOOLS USED}

Following standardized tests has been used by the investigator for collection of data:

- Managerial Creativity Scale (MCrS): by Sangeeta Jain, Rajnish Jainand and Upinder Dhar (2000).

○ Work Motivation Questionnaire (WMQ): by K. G. Agarwal (1997).

○ Occupational Self Efficacy Scale (OSES): by Sanjyot Pethe, Sushama Chaudhari and Upinder Dhar (2006).

\section{STATISTICAL TECHNIQUES USED}

Following statistical techniques were used by the investigator for analysis and interpretation of data:

○ (a) t-test

$\circ$ (b) Co-relation 


\section{Result Analysis And Main Findings}

\section{Result Pertaining To Managerial Creativity Of Secondary School Male And Female Tribal Teachers}

To find out the difference in managerial creativity among secondary school male and female tribal teachers, t-test was computed and the result is presented in table no.1

TABLE NO. 1: Results Of T-Test On Managerial Creativity Of Male And Female Tribal Secondary School Teachers

\begin{tabular}{|c|c|c|c||c|c|}
\hline Gender & N & Mean & SD & SEd & t- ratio \\
\hline Male & 30 & 95.53 & 10.52 & & \multirow{2}{*}{0.65} \\
\hline \hline Female & 30 & 95.66 & 10.04 & 0.05 \\
\hline
\end{tabular}

Level of significance at $0.05=2.00$, Level of significance at $0.01=2.66$

The Table No.1 depicts that the calculated t-ratio of managerial creativity of secondary school male and female tribal teachers is 0.05 which is not significant at 0.05 and 0.01 level. Thus, the proposed hypothesis that statedthere exists no significant difference in managerial creativity of secondary school male and female tribal teachers is accepted.

Result Pertaining To Work Motivation Of Secondary School Male And Female Tribal Teachers

To find out the difference in work motivation among secondary school male and female tribal teachers, t-test was calculated and the result is presented in table no.2

TABLE NO. 2: Results Of T-Test On Work Motivation Of Male And Female Tribal Secondary School Teachers

\begin{tabular}{|c|c|c|c|c|c|}
\hline Gender & N & Mean & SD & SEd & t- ratio \\
\hline Male & 30 & 92.36 & 13.12 & & \\
\cline { 1 - 4 } Female & 30 & 94.4 & 11.58 & 3.19 & 0.63 \\
\hline
\end{tabular}

Level of significance at $0.05=2.00$, Level of significance at $0.01=2.66$

The Table No.2 depicts that the calculated t-ratio of work motivation of secondary school male and female tribal teachers is 0.63 which is not significant at both the levels. Thus, the proposed hypothesis that stated there exists no significant difference in work motivation of secondary school male and female tribal teachers is accepted.

\section{Result Pertaining To Occupational Self-Efficacy Of Secondary School Male And Female Tribal Teachers}

To find out the difference in occupational self-efficacy among secondary school male and female tribal teachers, $\mathrm{t}$-test was applied and the result is presented in table no. 3

TABLE NO. 3: Results Of T-Test On Occupational Self-Efficacy Of Male And Female Secondary School Tribal Teachers

\begin{tabular}{|c|c|c|c||c|c|}
\hline Gender & N & Mean & SD & SEd & t- ratio \\
\hline Male & 30 & 72 & 9.55 & & \multirow{2}{*}{2.36} \\
\hline Female & 30 & 70.86 & 8.73 & \\
\hline
\end{tabular}

Level of significance at $0.05=2.00$, Level of significance at $0.01=2.66$

The Table No.3 depicts that the calculated t-ratio of occupational self efficacy of secondary school male and female tribal teachers is 0.47 which is found to be not significant at 0.05 and 0.01 level. Thus, the proposed hypothesis that stated there exists no significant difference in occupational self efficacy of secondary school male and female tribal teachers is accepted.

Result Pertaining To The Relationship Between Managerial Creativity And Occupational Self-Efficacy Of Secondary School Tribal Teachers

To find out the relationship between managerial creativity and occupational self-efficacy of secondary school tribal teachers, Pearson's coefficient of correlation was calculated and the result is presented in table no. 4 
Managerial Creativity And Work Motivation Of Secondary School Tribal Teachers In Relation To

TABLE NO. 4: Result Of Co-Efficient Of Correlation Between Managerial Creativity And Occupational Self-Efficacy

\begin{tabular}{|c||c||c||c|c||c||}
\hline Variables & N & M & S.D & $\begin{array}{c}\text { Co-efficient of } \\
\text { Correlation }\end{array}$ & Level of Significance \\
\hline \hline Managerial Creativity & 60 & 95.6 & 10.19 & & 0.38 \\
\hline $\begin{array}{c}\text { Occupational Self } \\
\text { Efficacy }\end{array}$ & 60 & 71.43 & 9.09 & $\begin{array}{c}\text { Significant at } 0.05 \text { and } \\
0.01 \text { level }\end{array}$ \\
\hline
\end{tabular}

Table value at 0.05 and 0.01 level of significance is 0.250 and 0.325

The table 4 depicts that the co-efficient of correlation between managerial creativity and occupational self efficacy of secondary school tribal teachers is positive and significant at both the levels i.e. 0.05 and 0.01 . Therefore, it can be interpreted that there exists positive relationship between managerial creativity and occupational self efficacy of secondary school tribal teachers.

Result pertaining to the relationship between work motivation and occupational self efficacy of secondary school male tribal teachers

To find out the relationship between work motivation and occupational self efficacy of secondary school male tribal teachers, Pearson's co-efficient of correlation was calculated and the result is presented in table no.5

TABLE NO. 5: Result Of Co-Efficient Of Correlation Work Motivation And Occupational Self Efficacy Of Secondary School Male Tribal Teachers

\begin{tabular}{|c|c||c|c||c||c||}
\hline Variables & $\mathbf{N}$ & $\mathbf{M}$ & S.D & $\begin{array}{c}\text { Co-efficient of } \\
\text { Correlation }\end{array}$ & Level of Significance \\
\hline \hline Work Motivation & 30 & 92.36 & 13.12 & & $\begin{array}{c}\text { Not significant at both } \\
\text { the levels }\end{array}$ \\
\hline \hline $\begin{array}{c}\text { Occupational Self } \\
\text { Efficacy }\end{array}$ & 30 & 72 & 9.55 & 0.08 & \\
\hline
\end{tabular}

Table value at 0.05 and 0.01 level of significance is 0.250 and 0.325

The table 5 depicts that the co-efficient of correlation between work motivation and occupational self efficacy of secondary school male tribal teachers is not significant at both the levels. Therefore, it can be interpreted that there exists no significant relationship between work motivation and occupational self efficacy of secondary school male tribal teachers.

Results Pertaining To Relationship Between Work Motivation And Occupational Self Efficacy Of Secondary School Female Tribal Teachers.

To find out the relationship between work motivation and occupational self efficacy of secondary school female tribal teachers' correlation was calculated and the result is presented in table No.6.

Table 6 Result of co-efficient of correlation between Work motivation and Occupational Self Efficacy of Secondary School Female Tribal Teachers

\begin{tabular}{||c|c||c||c||c||c||}
\hline Variables & $\mathbf{N}$ & $\mathbf{M}$ & S.D & $\begin{array}{c}\text { Co-efficient of } \\
\text { Correlation }\end{array}$ & $\begin{array}{c}\text { Level of } \\
\text { Significance }\end{array}$ \\
\hline \hline Work Motivation & 30 & 94.4 & 11.58 & & 0.28 \\
\hline $\begin{array}{c}\text { Occupational Self } \\
\text { Efficacy }\end{array}$ & 30 & 70.86 & 8.73 & $\begin{array}{c}\text { Significant at } 0.05 \\
\text { level }\end{array}$ \\
\hline
\end{tabular}

Table value at 0.05 and 0.01 level of significance is 0.250 and 0.325

The table 6 depicts that the co-efficient of correlation between work motivation and occupational self efficacy of secondary school female tribal teachers is positive and significant at 0.05 level. Therefore, it can be interpreted that there exists positive relationship between work motivation and occupational self efficacy of secondary school female tribal teachers. 


\section{RESULT OF t-TEST}

* There exists no significant difference in managerial creativity of secondary school male and female tribal teachers. The main reason being that both male and female teachers use novel ways to achieve organisational goals. They possess managerial competence and divergent thinking to the problem solving process.

* There exists no significant difference in work motivation of secondary school male and female tribal teachers. The main reason being that both male and female teachers get easily motivated towards work. They are cooperative, responsible, and confident and are well satisfied with their job.

* There exists no significant difference in occupational self efficacy of secondary school male and female tribal teachers. The main reason being that both male and female teachers are occupationally efficient. They are well satisfied with their job, interested in taking challenges, free to act and develop skills and abilities. They are aware of their responsibilities, loyalties, and tolerant towards their work.

- There exists positive relationship between managerial creativity and occupational self efficacy of secondary school tribal teachers. The reason being that the tribal teachers have divergent thinking to the problem solving process, they are innovative and prefer to learn through free exploration. Tribal teachers are capable to organize and execute the courses of action required to produce given attainments.

* There exists no significant relationship between work motivation and occupational self efficacy of secondary school male tribal teachers. This depicts that secondary school male tribal teacher's show low level of occupational self efficacy in comparison to work motivation. The main reason being that there is much more dearth of proper training for the professional development of tribal teachers on a large scale. There is no arrangement of monthly regular and fair assessment to teachers of the tribal community for the evaluation of their performance.

* There exists positive relationship between work motivation and occupational self efficacy of secondary school female tribal teachers. The main reason being that the female teachers are competent in creative learning and occupational self efficacy. They are satisfied with their job, interested in taking new challenges, free to act and develop skills and abilities. They are aware of their responsibilities, loyalties, and tolerant towards their work.

\section{LIMITATIONS}

From the present study, the researcher considered the following limitations:

* Collection of data within a stipulated period of time from different districts is one of the limitations.

* Some teachers were feared from higher authority and hesitated to give their own personal views. This may also cause variation in the results.

* As the language of the items of the scales was very difficult to be undertaken by some respondents. It also creates major barriers during data collection.

* There are total 22 districts in Jammu and Kashmir State, but the study was restricted to Kulgam, Anantnag and Shopian districts only. It can be studied on other districts also.

* Only tribal teachers were included in the sample. Other castes were not taken in the study.

\section{SUGGESTIONS}

The suggestions for further research that could be undertaken by perspective of researchers are:

* The further study can be conducted on a large sample.

* A Comparative study may be conducted to find out managerial creativity and work motivation of secondary school tribal teachers in relation to their occupational self efficacy.

* A similar study can be conducted on large scale at other state, covering all the districts of the particular state.

- A similar study may be conducted to find out managerial creativity and work motivation of secondary school rural and urban teachers in relation to their occupational self efficacy.

* A similar study can be carried out on Primary, Elementary, Higher Secondary and college level teachers.

* A similar study can be conducted keeping in view the other castes also.

\section{RECOMMENDATIONS}

* The secondary school teachers should be energetic, punctual, honest, cooperative and creative. They are supposed to be highly educated with sufficient scientific knowledge about the growing discipline of educational administration.

* The male teachers should use novel ways to achieve organisational goals. They should be cooperative, responsible and well satisfied with their job.

* Training agencies may arrange training programs for the professional development of the teachers on large scale. In such agencies qualities, like satisfaction with job, assignment planning, trust and confidence, group cooperation, managerial creativity, motivation towards work and responsibility should be imbibed among them. 
* Training institutions especially National University of Educational Planning and Administrations (NUEPA), National Council for Educational Research and Training (NCERT), Institute of Management for Planning and Administration (IMPA), State Institute of Education (SIE) etc. should augment the training programme to tribal teachers.

* Monthly regular and fair assessment of teachers especially of the tribal community would be of great value in the evaluation of their performance. So for this purpose a proforma for monthly evaluation of teachers" performance may be developed.

* Un-necessary duties and meetings should be avoided in order to reduce the pressure of the office work. This is necessary for the teachers to devote maximum time to academics for enhancing managerial creativity, work motivation and occupational self efficacy.

* Programs to increase the managerial creativity, work motivation and occupational self efficacy of teachers should be launched by government and private managements so to get the maximum productivity in the form of performance of teachers.

* It is strongly recommended that every secondary school should have guidance and counselling centre run by qualified and trained counsellors to overcome the problems of students.

* The tribal teachers should be given special incentives, promotion in order to reward their performance in their field.

[1] Adams, J. S. (1965). Inequity in social exchange. In L. Berkowitz (ed.), Advances in experimental social psychology. New York: Academic Press.

[2] Amabile, T. M. (1983).The Social Psychology of Creativity. New York: Springer-Verlag.

[3] Amabile, T. M. (1987). The Motivation to be creative. In S. G. Isaken (ed.), Frontiers of Creativity Research: Beyond the Basics, Buffalo, N. Y: Bearly.

[4] Amabile, T. M. (1990). Within you, Without you: The Social Psychology of Creativity and Beyond. In M. A. Runco and R. S. Albert (eds.), Theories of Creativity, Newbury Park, CA: Sage.

[5] Amabile, T. M. (1996). Creativity in Context: Update to the Social Psychology of Creativity, Boulder: Westview Press.

[6] Amabile, T. M. (1997). Motivating Creativity in Organisations: On doing what you Love and Loving What you do. California Management Review, Vol. 40, pp. 39-58.

[7] Assor, A. (2009). Enhancing Teachers' Motivation to Apply Humanist Information Technology Innovations. A Journal of Policy Futures in Education, Vol. 2, No. 6, pp. 662-669.

[8] Akande, A. (1997). Creativity: The Caregiver's Secret Weapon. An International Journal of Early Child Development and Care, Vol. 134, pp. 89-101.

[9] Bandura, A. (1977). Self Efficacy- Towards a Unifying Theory of Behavioural Change. Psychological Review, Vol. 84, pp. 191215.

[10] Bandura, A. (1997). Self-efficacy: The Exercise of Control. New York: Freeman.

[11] Bandura, A. (1986). Social Foundations of Thought and Action- A Social Cognitive Theory. Englewood Cliffs, New Jersey: Prentice Hall.

[12] Bandura, A. (1997). In F. Pajares, Directions in Self Efficacy Research: Self Efficacy Paper Presented at Annual meeting of the American Educational Research Association, New York, from the World Wide Web.

[13] Barron, Frank. (1969). Creative Person and Creative Process, New York: Holt, Rinehart and Winston.

[14] Betz, N.E., Hackette, G. (1981). The Relationship of Career Related Self Efficacy Expectations to Perceived Career Options in College Men and Women. Journal of Counselling Psychology, Vol. 28, pp. 399-410.

[15] Convey. John, J. (2010). Motivation and Job Satisfaction of Catholic School Teachers. Online Submission, Paper presented at the Annual Meeting of the American Educational Research Association.

[16] Collins, J. L. (1982) in T.P. Gornet, J.D. Kudisch and E.P. Gyman (1998). The Social Validity: Alternative Selection Procedures: The Relationship between Individual Differences and Applicant Reactions, Work in Progress, from the World Wide Web.

[17] Czikszentmihalyi, M. (1990). The Domain of Creativity. In M.A. Runco and R.S. Albert (eds.), Theories of Creativity, Newbury Park, CA: Sage.

[18] Graham, S., Weiner, B. (1996). Theories and Principles of Motivation. In D. C. Berliner and R. C. Calfees (Eds). Handbook of Educational Psychology, (pp. 63-84) New York: Simon and Schuster Macmillan.

[19] Deci, E. L., Ryan, R. M. (1985). Intrinsic Motivation and Self-Determination in Human Behavior. New York: Platinum.

[20] DeLong., Thomas, J., \& Richard. (1978). Career Planning for the Educator: Validating Current Career Development Theories. New York: Academic Press.

[21] DeLong., Thomas, J. (1981). Career Anchors: A New Concept in Career Development for the Professional Educator. New York: Academic Press.

[22] DeLong., Thomas, J. (1982). Career Orientations of Rural Educators: An Investigation. New York: Academic Press.

[23] DeLong., Thomas, J. (1983). A Career Development Perspective of Rural Educators and Career Decision-Making. New York: Academic Press.

[24] Flores., Belinda, B., Clark., \& Ellen, R. (2004). A Critical Examination of Normalistas' Self-Conceptualization and TeacherEfficacy: Hispanic Journal of Behavioural Sciences, Vol. 33, pp. 78- 88.

[25] Ford, D.Y., Harris, J.J. (1992). The Elusive definition of Creativity. Journal of Creative Behaviour, Vol. 26, pp. 186-198.

[26] Guilford, J.P. (1950). Creativity. American Psychologist, Vol. 5, pp. 444-454.

[27] Gundry, L. K., Kickul, J.R., \& Prather, C.W. (1994). Building the Creative Organisation. Organisational Dynamics, pp. $22-23$.

[28] Garrett, H.E. (1971). Statistics in Psychology and Education, Bombay: Vakils, Feffer and Simons.

[29] Hackman, J.R., Oldham, G.R. (1980). Work Redesign. M.A: Addison-Wesley, Reading.

[30] Hertzberg, F. (1959). Motivation to Work. New York: John Wiley.

[31] Hackette, G. (1981). In Nancy Betz and G. Hackette: Occupational Self efficacy Scale, from the World Wide Web.

[32] Hackette, G., Kuhl, J. (1992). In Nancy Betz and G. Hackette: Occupational Self efficacy Scale, from the World Wide Web. 
[33] Jesus, S. N., Lens, W. (2005). An Integrated Model for the Study of Teacher Motivation. Applied Psychology: An International Review, Vol. 54, No.1 pp. 119-134.

[34] Kao, John. (1991). Managing Creativity, New Jersey: Prentice Hall.

[35] Kerlinger, F. N. (1973). Foundations of behavioral research. New York: Holt, Rinehart, \& Winston.

[36] Kneller, G.F. (1965). The Art and Science of Creativity. New York: Holt, Rinehart and Winston.

[37] Koestler, A. (1964). The Act of Creation. New York: Macmillan.

[38] Lent, R. W., Brown, S. D., \& Larkin, K. C. (1986).Self Efficacy in Prediction of academic Performance and Perceived Career Options. Journal of Counselling Psychology, Vol. 31, pp. 265-269.

[39] Lent, R. W., Hackette, G. (1987). In Nancy Betz and G. Hackette. Occupational Self efficacy Scale, from the World Wide Web.

[40] McGregor, D. (1960). The Human Side of Enterprise, London: McGraw-Hill.

[41] McGregor, D. (1987). The Human Side of Enterprise, 2nd Ed, Harmondsworth: Penguin.

[42] Mackinnon, D. (1962). The Nature and Nurture of Creative Talent. American Psychologist, Vol. 17, pp.484-495.

[43] Marlatt, B., Quigley (1995). In Bandura A. (ed.). Self Efficacy in Changing Societies, New York: Cambridge University Press.

[44] Marsh, H.W., Debus, R. (1991). Subject- Specific Components of Academic Self Concept and Self efficacy. Contemporary educational Psychology, Vol. 16, pp. 331-345.

[45] Mumaw., Catherine, R. (1995). Teacher Efficacy and Past Experiences as Contributors to the Global Attitudes and Practices among Vocational Home Economics Teachers: Family and Consumer Sciences Research Journal, Vol. 55, pp. 105-110.

[46] Meister., Denise, G. (2010). Experienced Secondary Teachers' Perceptions of Engagement and Effectiveness: A Guide for Professional Development. Qualitative Report, Vol. 15, No. 4, pp. 880-898.

[47] Newkirk., Catherine, E. P., \& Klotz, J. (2002). Teacher Self-Efficacy and Site-Based Management as a Decentralization Strategy.

[48] Osborn, A.P. (1953). Applied Imagination. New York: Scribrur.

[49] Pajares, F. (1996). Directions in Self Efficacy Research: Self Efficacy Paper Presented at Annual Meeting of the American Educational Research Association New York, from the World Wide Web.

[50] Pareek, U. (1987). Motivating Organisational Role, Jaipur: Rawat.

[51] Rhodes, M. (1961). Analysis of Creativity. Phi Delta Kappa XLII (42).

[52] Richards, T. (1988). Creativity and Innovation: A Transatlantic Perspective. In Creativity and Innovation Yearbook, Vol. 1, pp. 69-77.

[53] Rosenberg, M., Kapland, H. B. (1982). Social Psychology of Self Concept, Arlington Heights, IL: Harlan Davidson.

[54] Runhaar., Piety., Sanders., Karin., Yang., \& Huadong. (2010). Stimulating Teachers' Reflection and Feedback Asking: An Interplay of Self-Efficacy, Journal of Research and Studies, Vol. 26, No. 5, pp. 1154- 1161.

[55] Schavelson, R. J., Bolus, R. (1982). Self Concept: The Interplay of theory and models. Journal of educational Psychology, Vol. 74, No. 3-17.

[56] Schwarzer, R. (1994). In James Mc Cormick, General Perceived Self efficacy in 14 Cultures, Frecie University, Berlin Abstract, from the World Wide Web.

[57] Simon, H.A. (1988). Understanding Creativity and Creative Management. In R.L. Kuhn (ed.), Handbook for Creative and Innovative Managers. New York: McGraw Hill.

[58] Torrance, E.P. (1979). The Search for Satire and Creativity. Buffalo, New York: Creative Education Foundation.

[59] Taylor. Betz, N. (1983). In Nancy Betz and G. Hackette. Occupational Self efficacy Scale, from the World Wide Web.

[60] Tripp, M. A. (1997). Perspective on the Development and Influence of Self efficacy Beliefs, from the World Wide Web.

[61] Walls, G. (1926). The Art of Thought. New York: Harcourt, Brace.

[62] Wiegman., John R., Binnie., \& David G. Attitudes toward Merit Pay for Instructional Personnel: A Survey of Florida Public District Policy Makers and Administrators. Florida Educational Research and Development Council, Inc. Research Bulletin, Vol.19, No. 2 .

[63] Woolfolk, A. E., Rosoff, B., \& Hoy, W.K. (1990). Teachers' Sense of Self Efficacy and Beliefs about Control. Journal of Educational Psychology, Vol. 82, pp. 81-91.

[64] Yu-Kwong, Y., Paula, K., Walker., \& Allan. (2010). Secondary School Vice-Principals: Commitment, Challenge, Efficacy and Synchrony: British Educational Research Journal, Vol.36, No. 4, pp. 531-548.

[65] Zaleznick, A. (1988). Making Managers Creative: The Psychodynamics of Creativity and Innovation. In R.L.Kuhn (ed.), Handbook for Creative and Innovative Managers. New York: McGraw Hill. 